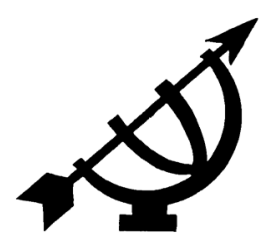

\title{
Leadership style in Swiss evangelical churches in the light of their historically shaped leadership culture
}

\author{
M. Russenberger 1 \\ Department of Practical Theology \\ University of South Africa \\ PRETORIA \\ and \\ Chrischona-Gemeinde Hallau \\ Hallau \\ Switzerland \\ E-mail: Michael.russenberger@chrischona.ch
}

\begin{abstract}
Leadership style in Swiss evangelical churches in the light of their historically shaped leadership culture

This article is a sociological-historical study of the inter-relation between the historically developed leadership culture of democracy and leadership practice in the evangelical churches of Switzerland. Contemporary Swiss leadership style is based on the cultural inheritance of the Celts, the Romans and the Germanic tribes, the foundation of the Confederation, as well as the history of Christianity. The core values that shaped Swiss leadership culture are the idea that not too much power should vest in the individual, that there should be a democratic right of co-determination, that there should be federal freedom, and that work and achievement are very important. These same basic values still affect leadership in Swiss evangelical congregations today.
\end{abstract}

1 The research on which this article is based was undertaken while Michael Russenberger was registered as an M.Th. student in the Department of Practical Theology at the University of South Africa under the supervision of Professor Johan Wolfaardt and Dr Volker Kessler. 


\title{
Opsomming
}

\section{Leierskapstyl in Switserse evangeliese kerke in die lig van hulle histories-gevormde leierskapskultuur}

\begin{abstract}
Hierdie artikel is 'n sosiologies-historiese studie van die interrelasies tussen die histories ontwikkelde leierskapskultuur van demokrasie en leierskapsbeoefening in die evangeliese kerke van Switserland. Switserse leierskapstyl is tans gebaseer op die kulturele erfenis van die Keltiese, Romeinse en Germaanse stamme, op die fondament van die Konfederasie, sowel as die geskiedenis van die Christendom. Die kernwaardes wat Switserse leierskapskulture vorm, is die idee dat daar nie te veel mag by die individu moet berus nie, dat daar 'n demokratiese reg of gesamentlike vasberadenheid moet wees, dat daar 'n federale vryheid moet wees en dat werk en prestasie baie belangrik is. Dieselfde basiese waardes beïnvloed steeds leierskap in Switserse evangeliese gemeentes vandag.
\end{abstract}

\section{Introduction}

Swiss history is characterised by a long fight for freedom from any kind of heteronomy and oppression with the goal of democratic brotherly fellowship. Like any other nation, Switzerland has a certain ethnic character which gives expression to and cultivates a particular leadership culture. Only those leaders who truly understand and accommodate cultural characteristics will ultimately be able to achieve results in any Swiss enterprise, to do justice to the Swiss, and to win them over. This is also supported by intercultural management theory in the age of globalisation and confirmed by various scientific studies (Rothlauf, 1999:7). In theology it is a natural part of missiology. Unfortunately, however, present-day Christian and non-Christian leadership and management practice pay little heed to these insights. Generally it is assumed that there is one absolute biblical leadership theory, irrespective of culture, which applies to Christians universally. Missionary work, though, shows clearly that, depending on the nation and its history, deep-rooted cultural values related to power and leadership can have their very own and various expressions (Roembke, 2000:182).

Cultural relevance in leadership practice has not only become an important topic within missiology, but has recently received more attention among leaders of Christian organisations operating within their own cultural groups (Newbigin, 1989:7 ff., 129). In the case of a leader, an appreciation or, conversely, a lack of understanding of his/her own culture will determine his/her attitude and actions as well as his/her choice of leadership structures and styles. Only with an 
awareness of his/her cultural background can a leader reflect on his/her leadership style and effectively apply leadership theories from other cultures.

God seems to accept cultural diversity. He makes this particularly clear through his plan of salvation for all nations (Gen. 12:2; Matt. 28:18-20) and through the example of Christ in his incarnation and dedication to humankind (Phil. 2:5-8; Mark 10:43, 44). Therefore, Christians should regard culture neither as being negatively hostile, nor as being positively divine (Niebuhr, 2001:190 ff.; Kraft, 1991: 113). Culture may be regarded as generally neutral even though it has been perverted by the influence of human sin. For this reason an acknowledgement of the importance of cultural relevance needs to be a part of executive management in Switzerland and may only be achieved by consideration of and commitment to cultural values. Even the correction or application of different leadership decisions based on biblical orientation are only feasible and effective if cultural values are recognised and evaluated.

The first part of this article deals with the historical development of basic leadership qualities. The main focus is on the following three emerging aspects of Swiss democracy:

- A constant outward and inward struggle for freedom and independence

- Decentralised federalism

- The principle of equality for all, which grants final authority to the people's assembly

This article concentrates mainly on the German speaking northern region. Nevertheless, historical leadership values and their influence apply to the whole of Switzerland.

\section{Swiss leadership culture in its historical development}

Core cultural values are enormously persistent and can be traced back a long way. This explains why cultural characteristics penetrate all aspects of life and hardly change. This section will concentrate on the earliest development of democracy, the foundation of the Swiss Confederation and the history of Christianity. 


\subsection{Three historic roots of democratic leadership culture in Switzerland}

Three cultural roots form the foundations and origins of Switzerland.

\subsubsection{The cultural legacy of the Celts: fifth to the first century $B C$}

It is widely assumed that the Celtic tribe of Helvetians in Southern Germany migrated to the territory of what is today known as Switzerland at the end of the second century BC (Furger-Gunti, 1986:77). The broad spread of the Celtic tribes is astonishing since they did not have any central power to provide cohesion nor a coordinated strategy for expansion.

Pressured by the Germanic tribes in the North and by the Romans in the South, and driven by their Celtic restlessness as well as the degradation of the meagre pastures between the Alps and the Rhine, they decided to migrate further into Southern Gaul. Under the leadership of the rich and noble Orgetorix they prepared this migration for a period of two years. Just before their planned departure, Orgetorix' plans were discovered as was his objective to make himself emperor of the new territory. Such action was punishable by burning. Orgetorix chose to abscond from justice and committed suicide (Dändliker, 1884:50). However, the Helvetians kept to the decision taken by the people, burnt their twelve towns and 400 villages and left in the direction of what is now Geneva. There they were stopped and defeated by Caesar in $58 \mathrm{BC}$. The remnants of their tribe were forced to return to their homelands in the presently Northern Switzerland to rebuild their homes. Switzerland then became a Roman province. Caesar intended to use the Celts as watchmen against their common foe, the Germanic tribes in the North, and contracted them for that purpose (Dändliker, 1884:53). After several futile efforts to gain freedom from the Romans, the Helvetians finally settled down under Roman rule. Generally speaking, Rome's presence in Switzerland was relatively limited, and so the majority of the population of Roman Switzerland remained Celtic. The cultural legacy of the Helvetian Celts is their democratic values, which have become a deep-rooted principle of today's Swiss leadership culture. This legacy is distinguished by the following characteristics.

\section{- $\quad$ Federalistic fellowship}

The Celts did not have a central government. They were autonomous yet associated tribes, and they spread out together. They loved their tribal, individual and natural freedom. However, these 
characteristics prevented them from becoming a strong nation in the long run. They were unable to prevail against other nations and lived as a fragmented and unstable people. Their individualistic yearning for freedom led them to become rather wild, immoral and underdeveloped people (Dändliker, 1884:48 ff.).

\section{- Democratic people's sovereignty}

In all the Celtic regions, even outside of Switzerland, for example in Ireland and Gaul, all the important decisions were made by the people (De Vries, 1961:236).

\section{- $\quad$ Fragmentation as a response to the leadership elite}

The Celtic ideal of federalism and democracy was basically a certain brotherly fellowship of free commoners. Again and again this ideal was subverted by an oligarchy and consequently an autocratic type of government. Then, again and again the dominant elite were overthrown by a people's revolution or other dramatic intervention from the outside. The overthrowing of authorities was once more followed by fragmentation into small, autonomous or half-autonomous units or localities where there was an absence of the greater structures of an organised regime. The tendency to fragmentation seems to be the origin of federalism (Todd, 1985:58).

\subsubsection{The cultural legacy of the Romans - $58 \mathrm{BC}$ to $401 \mathrm{AD}$}

After Caesar's defeat of the Helvetic Celts in Switzerland, their territory was occupied by Roman troops and became part of the Roman Empire. Since the Roman conquerors mainly ruled the cities, independent villages could still be found in rural areas, where, among other things, they were allowed to take certain decisions collectively (Dändliker, 1884:56). On several occasions the Celts revolted unsuccessfully against the Roman conquerors. Despite their discomfort at their subordinate status the "wild and barbarous" Celts eventually benefited from the highly developed Roman civilisation. Since there was no intermarriage between the Romans and Celts, the following basic values of Celtic culture were cemented.

\section{- Federalism and democracy despite authoritarian, hierarchic rule}

The Roman Empire ruled for about 400 years with its rigid hierarchic structure and central exercise of power. However, as the majority of Celts in Switzerland lived in rural areas, outside the cities as independent and self-governing units, village communities continued to practice democratic people's sovereignty. 


\section{- $\quad$ Struggle for freedom and independence}

Several rebellions during the period of Roman rule demonstrated the ongoing struggle for freedom and independence. This struggle for freedom during a time of oppression was also expressed and proclaimed through a linguistic dichotomy. Historical research confirms the fact that the Celtic language was spoken during the entire period of Roman occupation. At the same time it seems that Latin was accepted as the official written language (Furger-Gunti, 1986:131). Today, the use of dialect still serves as a means of separation from the neighbouring countries of Austria and Germany as well as in Switzerland itself, to mark federal distinctions between village and village and region and region (Furger-Gunti, 1986:47; Watts, 1996: 139).

\subsubsection{The cultural legacy of the Germanic Alemans: beginning from the fifth century $A D$}

Until the fourth century $A D$ the Alemans repeatedly invaded the Northern Roman Empire in order to loot, kill and burn (Müller, 1975:20-44). In 401 AD the Roman occupation of Switzerland came to an end leaving behind the weak and romanised Celts (Dändliker, 1884:76). Celtic values became mixed with Alemanic values and slowly a new Celtic-Alemanic culture emerged. Compared to the Roman era, the Germanic era brought about more substantial and more lasting change to the German speaking Swiss culture. This was characterised by the following values.

\section{- Federalism of togetherness and personal freedom}

Unlike the Celts, the Alemans were to some extent organised hierarchically based on the old Germanic troop organisation. The Alemans avoided large urban settlements because of their love for freedom and movement. Especially during the early centuries they preferred to built "scattered, isolated farmsteads where everyone was able to do as they pleased, living in complete independence for themselves and their individual preferences" (Dändliker, 1884:87). We can trace the typical Swiss culture of togetherness combined with the need for local and individual freedom back to the Alemans. Their almost democratic treatment of classes became the federal root of today's Swiss leadership culture. Nobility enjoyed only a few privileges (Dändliker, 1884:94). 


\section{- $\quad$ Alemanic democratic fellowship}

The Alemanic democratic roots of Switzerland lie in the people's assemblies which served as civil and military tribunals. These people's assemblies vanished under the rule of the Franks in the fifth century $A D$, yet surfaced again in the thirteenth century in the form of the community councils (Landsgemeinde) in central Switzerland. In some Swiss cantons they have survived until today as people's assemblies with decision making authority.

\section{- Resistance to tyranny}

Unlike in the case of the Celts, within Alemanic society, there was a clear hierarchic structure in all the tribes. Nevertheless, the Alemans also embraced personal freedom and the rights of the individual, and kept social class differences within limits.

Quite soon, during their colonisation of Switzerland in the middle of the sixth century, the Alemans were conquered by the Franks (Dändliker, 1884:101). Having to live under someone else's rule was to be the Swiss' fate until the foundation of the Confederation in 1291. Similarly to the Celts under Roman rule though, they were able to preserve relative local independence despite foreign occupation. For several centuries, however, the Alemans struggled against and fought those foreign authorities.

\subsection{The history of the Swiss Confederation and the development of a political-democratic leadership culture of Switzerland}

Switzerland is known to be one of the oldest democracies in the world (Linder, 1999:27) with a long and sometimes painful history. The historical development of the Confederation until its national foundation in 1848 is a logical consequence of its Celtic-Germanic cultural legacy of democracy and a struggle for freedom. This part of history also left a strong imprint on today's Swiss leadership style. Most of the Swiss core leadership values of political democracy were developed during this time and penetrated all spheres of society.

After the fall of the Carolingian Empire, the Middle Ages were characterised by much disorder, moral decline and particularly many battles for dominion. After Burgundy had been annexed, Switzerland became part of the Holy Roman Empire in 1032 AD. Most governance was the domain of the German monarchs. In the thirteenth century larger towns like Bern and Zurich had the status of "Free 
Empire Cities" and had extensive economic and political independence. The small and remote valleys of the Alps had always been independent. However, that independence was threatened when the Austrian Habsburg monarchy sent reeves to protect its income. This led to unrest throughout Habsburg territory. ${ }^{2}$ At this time representatives of the three central regions of Uri, Schwyz and Unterwalden entered into a pact of mutual assistance. After the German monarch Rudolf of Habsburg died in 1291, the oral pact was recorded in writing (Dändliker, 1884:391), which marked the official beginning of the Confederation (Augustiny, 2003). More and more free towns and counties joined the pact. The centuries following the foundation of the Confederation were marked by a struggle for independence and the need to expand its territory.

Under the rule of Napoleon, the cantons were united into a republic in terms of the French constitution. Napoleon, however, did not succeed in creating a centralised state with one central government. In 1815 the Confederation gained back its full independence. The equality of the cantons remained as a lasting accomplishment of the French Revolution (Linder, 1999:27). Switzerland was again a loose federation, although it took until after 1848 for it to get a parliament and executive organ.

Four political-democratic leadership values that still hold true today, emerged during the foundation of the Confederation and became established in political organisation.

\section{- $\quad$ Direct democracy}

The people have a right to codetermination and final authority in all important political issues on a constitutional level. This is made possible through citizens' initiative and mandatory referenda. The parliament decides on all issues on a legislative level. Even these rulings are subject to possible reconsideration by the people. A group of citizens can ask for a facultative referendum.

The highest government organ in Switzerland is the federal council (Bundesrat) consisting of seven members. It has existed since 1959, represents all four of the large national parties, and is conducted according to the principle of collective responsibility. The members of the federal council rotate in taking up the formal and represen-

2 The Habsburg territory covered all of Southern Germany, Austria and Northern Switzerland. 
tative functions of federal president one year at a time. The concept of direct democracy can be found on all levels - national, cantonal and local.

\section{- $\quad$ Swiss federalism}

Its main characteristic is the importance placed on largely autonomous member states (cantons). According to the legally anchored subsidiarity principle, the rules are fixed: "The national government may only execute those tasks that are explicitly stated in the constitution. All other issues are governed by the cantons." (Braun, 2003:93.)

\section{- Concordance}

The political value of concordance entails a continuing search for unity and agreement in all conflicts and differences. Political conflict management through negotiation and pragmatic consensus has become a typical Swiss virtue (Linder, 2002:26).

\section{- Neutrality}

Although there is a current tendency to regard political neutrality as outdated, politic-economically obstructive, and impracticable, Switzerland has tried to live a policy of neutrality since the Battle of Marignano in 1515. In 1815, Swiss neutrality was recognised by the leading powers of Europe in the Agreement of Wien (Linder, 1999: 32).

\subsection{History of Christianity within democratic Swiss culture}

Besides the historic roots of the first Celts and Alemans, as well as the politic-cultural development of the Confederation, religious development - in particular the history of Christianity - has also been a strong factor in determining Swiss culture. There is a clear mutual influence between the historically derived democratic leadership culture and the development of Christianity. There are three stages of Christianity which have particularly influenced and penetrated Swiss culture.

\subsubsection{The first stage of Christianity in the time of the Irish mission from the sixth to the eighth century}

On the whole, the Christianisation of the Celtic-Germanic Swiss by the ruling Franks happened very slowly, because, according to historiography, its introduction from above was impossible. That only changed when the first Irish-Celtic missionaries, Columban and 
Gallus, came to Switzerland in 610 AD. Without doubt it was them who finally brought Christianity to Celtic-Alemanic Switzerland through their cloistral way of life. They obviously succeeded because of their common Celtic descent. The Celtic mission's culture was characterised by federally and democratically organised convents. Their system of brotherly fellowship prevailed against centralistic, dictatorial claims and forms of organisation (Norton-Taylor, 1989:119).

\subsubsection{The second stage of Christianity - the reformation of Zwingli in the sixteenth century}

More than any other movement, the Reformation affected and changed Switzerland on a political, social and most of all religious level in only a short period of time. The Reformed Church of Switzerland created a new clerical structure and a spiritual concern in its regions which were influenced by the democratic thinking of the time. The main originator of the Swiss Reformation, especially in Northern Alemanic Switzerland, was Huldrich Zwingli of Zurich. The Reformation in Zurich not only served a theological purpose, but was also an expression of the ancient struggle for freedom and independence. What was accomplished by the Confederation in 1291 on a political level was now also achieved on a clerical level. The Swiss culture of democracy experienced its breakthrough during the Reformation and influenced the development of state church culture. During that time the core leadership values of democracy were expressed in several ways.

\section{- $\quad$ The Reformation in Zurich reflected the ancient leadership} style of resistance against foreign rulers

Hence the separation from the Catholic domain took place on a clerical level. Even the Catholic central Swiss cantons, which were already largely autonomous from Rome, were strengthened by the Reformation.

\section{- $\quad$ Swiss democratic federalism was now established in the church through the Reformation}

The Catholic Church's hierarchic rule in Switzerland as a whole disintegrated during the Reformation and was replaced by independent sovereignty of each place or canton. Reformed cantons even introduced a federal church leadership. 


\section{- Democratic codetermination of the people found its place}

Secular councillors were given leadership positions in the church and so the people who had voted them into their guild, indirectly had the right of codetermination. Furthermore, the church was governed by church councils, supervisory boards and the synod of all preachers which ensured people's democracy to some extent.

\subsubsection{The third stage of Christianity - the establishment of free churches from the sixteenth to the nineteenth century}

For three decades, the Baptists and Pietists fought a two-fold struggle for freedom. On the one hand, they fought for the "individual and corporate right of religious self-determination". On the other hand, there was the internal political struggle for spiritual independence from the state church and for all churchgoers to share joint leadership responsibility, in other words, the establishment of a practicing common priesthood. Zwingli's state church was a first step towards democratic church freedom for all in Switzerland. Internally, however, Zwingli's state church retained its hierarchic power structure, which was aggravated by the fact that leaders held both secular and clerical positions. For all evangelical-pietistic minded church members that meant both religious incapacitation and ongoing cultural oppression. Swiss churchgoers did not have democratic federal rights of leadership.

Only with the Age of Enlightenment and the French Revolution did free churches slowly gain their independence from the state. By the end of the eighteenth century, societies or clubs came into existence. They became the first legal form of entities in Swiss history that were both fundamentally independent from the state, and also fully recognised by the state, which has not changed until now. About $89 \%$ of all religious fellowships in Switzerland are organised as societies (Rüegg, 2002:268, $396 \mathrm{ff}$.).

\section{Swiss leadership today}

Present leadership in Switzerland is primarily based on the historical development of many centuries and should be explained and understood against that background. 


\subsection{Four general core values of Swiss leadership culture today}

\subsubsection{No exclusive power to the individual}

The most important core value of Swiss leadership culture is historically derived from the ongoing common resistance in which the Swiss engaged against any form of foreign rule. This means that the Swiss are suspicious of any growing or lasting influence of an individual or a group and they will sooner or later resist such influence.

Therefore, a Swiss leader's power is always limited and temporary it is lent to him/her by the people (Müller, 1988:251). Those who lend power to a leader retain their autonomy and equality.

\subsubsection{The democratic right of codetermination}

Democracy as a means of codetermination by the individual in respect of important decisions, is another core value of Swiss leadership culture. From an early age children are trained to accept majority decisions. I realised that when I was present during my four year-old daughter's music class. The music teacher, an experienced and confident person, asked the children whether they wanted to have the end of year performance on the small stage or on the spacious open area next to it. After some discussion she asked the children to raise their hands and vote democratically. Contrary to her own preference, the impractical raised stage won by a close vote and she simply complied. The Swiss want to have a say, contribute and be involved in decisions (Guggenbühl, 1967:100).

\subsubsection{Federal association and individual freedom}

This politically deep-seated value of Swiss federalism has various aspects. One of them expresses an understanding of a loose alliance between equal, completely independent partners in an attempt to guarantee both parties' freedom. The Swiss want to see themselves or their groups administrated as autonomously as possible, yet they also regard themselves as equal members in partnership with other associated groups or a higher entity.

\subsubsection{Achievement and work are important}

The Swiss really value achievement and work. This value is rooted in a long European history (Weber, 1872:166 ff.) and seemingly contradicts postmodernity. Despite this, the significance of work and 
accomplishment remains a core value. Work and achievement give meaning and recognition to the Swiss as well as security and independence in life (Guggenbühl, 1967:43). People who do not work are very much looked down upon in Switzerland. Undoubtedly that "excessively developed need for security - an existential fear trying to eliminate any risks" (Guggenbühl, 1967:92) is the motivator for achievement and work. Similarly, the Swiss' love for regulations and laws helps them to overcome a sense of uncertainty and fear. At the same time any firm rules that conflict with the Swiss' drive for freedom and independence are resisted. Therefore, practical leadership often becomes difficult and generates tension.

\title{
3.2 The five cultural dimensions in Switzerland
}

A very significant study on comparing ethnic national cultures was carried out by the Dutch scientist, Geert Hofstede. He described five cultural dimensions and compared different countries with each other. The result of his study clearly reflects the historically developed values of Swiss leadership culture.

\section{- $\quad$ Power distance}

The term power distance relates to "the degree to which less powerful members of an institution or organisation expect or accept that power is unequally shared" (Hofstede \& Hofstede, 2009:522). In countries with a small power distance, the dependency of a subordinate on the supervisor is limited. A consultative style is practised. Switzerland is a country with a very small power distance.

\section{- The role of individualism versus collectivism}

\begin{abstract}
Individualism describes societies with loose connections between individuals. It is expected of the individual to care for him and the immediate family. The opposite - collectivism describes societies where individuals are born and integrated into strong exclusive 'we-groups' that on the one hand protect the individual all his life and on the other hand demands total loyalty. (Hofstede \& Hofstede, 2009:102.)
\end{abstract}

Switzerland has a strongly individualistic culture.

\section{- Masculinity versus feminism}

Masculinity within a society is expressed through dominant values such as the drive to earn money, get recognition, seek promotion and take on challenges at work. Feminism values include having a good working relationship with a superior, being able to work as part 
of a team, and the need to have comfortable surroundings and security at work (Hofstede \& Hofstede, 2009:164). In international comparisons Switzerland ranks near the top in terms of masculinity.

\section{- Uncertainty avoidance}

This is the "degree to which the members of a culture feel threatened by uncertain and unknown situations" (Hofstede \& Hofstede, 2009:233). Switzerland ranks as average, with a tendency to avoid uncertainties.

\section{- $\quad$ Short-term versus long-term orientation}

Values within a short-term culture are endurance, order and keeping the status of a relationship, economic talent and shame. "Short-term orientation esteems values related to the past and present, especially respect for traditions, keeping face and fulfilment of social duties." (Hofstede \& Hofstede, 2009:521.) Switzerland ranks as average in this respect (Hofstede \& Hofstede, 2009:294).

\subsection{Practical-theological leadership concepts in Swiss evangelical churches}

Theological leadership in Swiss evangelical churches varies, but there are many similarities with regard to the concept of theologically defined leadership and, therefore, it seems legitimate to speak of a basic concept of evangelical leadership in Switzerland. Its main features are summarised below.

\subsubsection{Swiss evangelical churches nurture culture-neutral leadership}

The basic leadership and organisational papers of most international church associations are almost identical. The main reason for that is that the theological understanding of a culture-neutral leadership practice is valid for all times and peoples. Besides its direct biblical basis, such understanding is also based on a commitment to the presbyterial concept of leadership (Rüegg, 2002:303) with its baptist and pietist roots (Eggenberger, 1990:55, $70 \mathrm{ff}$.). However, there are many more Bible based concepts of leadership and models. ${ }^{3}$

3 Cf. Stadelmann (1988:21 ff.) referring to three classical leadership models: the episcopal, the congregational and presbyterial leadership models - cf. also Jansen (1931). 
Culture-neutral leadership definitions are timeless, generally understood and serve as useful guidelines. They may, however, present potential problems and dangers for example claims for biblical and ultimate leadership statements. They may a priori exclude concepts of leadership based on national or situation specific aspects or tend to condemn other concepts of leadership. Finally, one sided cultureneutral concepts may create an incorrect sense of self-assurance and may make it difficult for a leader to accept criticism and correction.

\subsubsection{Leadership concepts are gift and ministry orientated}

Despite a wide range of opinions on the function and ministry of church leaders, there are some common biblical-theological perceptions shared by evangelical churches. On the one hand, most people regard leadership as a multifaceted spiritual gift (PM, 1983:14; FEG, 2001:36; Minichiello et al., 2002:17). Many church members are called, gifted and enabled by God to exercise leadership in different ways within the congregation. Leadership is viewed as a versatile task and gift of God which is carried out by many people complementing each other. This diversity is reflected in the broad spectrum of job descriptions related to church leadership.

Besides the general gift-orientated understanding of leadership, most free churches also acknowledge the official function of the church council. However, the existence of a multitude of gifts and ministries within the church does not always automatically lead to an official function in the church, let alone to a position in the church council.

\subsubsection{Swiss evangelical churches practise a presbyterial leadership style}

A presbyterial leadership style is combined with the Swiss democratic structure of its societies (Rüegg, 2002:303). The statutes of evangelical associations hold that the general meeting of the local congregation is the highest organ which administers matters such as finances, election of employees, leaders and other groups as well as decision making in all important issues (Rüegg, 2002:423 ff.). Spiritual leadership, teaching and executive power fall to the church council members, who are supported by deacons in some places. Swiss evangelical churches often base their presbyterial leadership practice on the three criteria found in Hebrews 13:17. 


\section{- $\quad$ A leadership council}

"Obey your leaders" (Heb. 13:17). The Bible always mentions leaders and elders in the plural. Evangelical churches in Switzerland are normally led by a group of elders with the fulltime pastor being an equal member of that council. Presbyterial leadership in free churches is always shouldered by a team that carries out the ministry together.

\section{- Theocratic leadership concept}

"They will give an account for their work" (Heb. 13:17). As in other countries God-given authority is assigned to elders and leaders in Swiss evangelical churches. In their religious office they stand directly under the leadership of and accountability to God (Acts 20:35; 1 Pet. 5:2) bearing the responsibility for the congregation's planning, teaching and personnel decisions (PM, 1998:13). Congregations are expected to respect their leaders' God-given authority. Above all, however, the congregation has the power to control and confirm (PM, 1998:6 ff.). Leadership in Swiss evangelical churches is neither executed by the congregation as in a people's democracy, nor is it executed sovereignly by the church council. Rather it is executed in joint responsibility of both in accountability to God.

\section{- $\quad$ Servant leadership}

"They keep watch over your souls" (Heb. 13:17). The church is the "body of Christ" and a non-clerical fellowship (PM, 1995:3) with elders and leaders conducting their ministry like other members (Rom. $12: 3 \mathrm{ff}$.). The ministry of elders is a task like any other and needs to be complemented by other church members who also are led by the Holy Spirit (PM, 1998:4).

\section{Evangelical leadership practice influenced by Swiss culture - observations}

After all that has been said, the question of how Swiss leadership culture manifests itself in evangelical leadership styles, needs to be explored. For that purpose, leading personalities from all the big church associations in Switzerland have been interviewed. The interview partners were Ines Adler (Salvation Army), Karl Albietz (Pilgermission St. Chrischona), Paul Beyeler (Association of Free Missions Churches), Herbert Henggi (Orphanage Selam), Iwano Lai (Pentecostal Churches), Georges Morand (Willow Creek Switzerland), Markus Müller (Pilgermission St. Chrischona), Hanspeter 
Nüesch (Campus Cursade for Christ), Walter Wilhelm (Methodist Churches), and René Winkler (Association of Chrischona Churches). 4

\subsection{No power for the individual: the difficult position of dominant authoritarian personalities}

Most of the executives who were interviewed immediately confirmed the observation that leaders with dominant authoritarian personalities encounter great difficulties in Swiss evangelical churches (Guggenbühl, 1967:35). Authoritarian leaders, who cannot convince their members and workers of their plans, involve them in carrying out these plans and give them some independence at work, will sooner or later be rejected. Swiss culture nurtures a deep distrust of dominant authoritarian leaders who "will eventually be overthrown" as the director of a church association puts it.

There are exceptions, though, in evangelical circles at least in the medium term, especially in youth movements, pioneer projects or individual congregations where well-known charismatic personalities are working.

Allowing an individual to have authoritarian power goes against the historically developed understanding of the Swiss and contradicts the concept of the practical theological leadership of the presbyterial leadership culture in Swiss evangelical churches. Church leadership is mainly based on Acts 20:28, 1 Peter 5:2-4 and Hebrews 13:7 (FEG, 2001:58; PM, 1998:13).

\subsection{Democracy: the demand for the right to codetermination and consensus}

In terms of the common priesthood of spirit-filled believers, not only Swiss free churches demand the right to have a say (Stadelmann, 1988:20). Biblical texts such as 1 Peter 5:2-4, Revelations 1:5 and Hebrews 7:23 ff. are the basis for the idea of common priesthood and a strong democratic understanding in Swiss evangelical churches. All the interviewees confirmed this. Workers must be involved in planning and the process of decision making in order to win them over. Naturally in Swiss evangelical churches all group and depart-

$4 \quad$ The interviews were conducted between November 2003 and February 2004. They are not representative, they only serve to qualify or confirm my observations. 
ment leaders are asked to give their opinions and ideas on issues that affect the whole congregation in order to avoid them withdrawing their involvement, attendance or respect. Whatever decision has been taken by a majority will then generally be accepted by all. A leader with a rather dominant authoritarian personality may find this way of doing things, including the need for communication, too arduous, unnecessary and an obstacle to effective progress (Seiwert \& Gay, 1996:22, 50).

\subsection{Federalism: the pursuit of small autonomous units}

Using the New Testament image of a body symbolising the fellowship of believers (1 Cor. 12; Rom. 12:4), evangelical churches explain and defend for federalism as it is practised in Switzerland. A passion for small autonomous units (Brück, 2002:165), however, reflects an essential characteristic of Swissness that corresponds with the historical development of the country. "Enthusiasm for club life" is an excellent means of reaching that goal (Rüegg, 2002:268, 369 ff.). Thus, until several decades ago, one or more sub-societies such as the brass band society or the choir society, each with its own general meeting, board, treasurer and president, could be found in free churches. These sub-societies had their own church-independent existence.

Besides fostering a drive for autonomy, Swiss federalism also has a tendency to encourage the formation of loose associations with other like-minded individuals. Autonomous groups such as those mentioned above rarely disassociate themselves from the local congregation.

\subsection{Performance orientation: accomplishment as proof}

In contrast to the situation in the neighbouring countries of Austria and Germany, the regional leaders of Swiss church associations confirm the fact that authority and acceptance of a leader does not automatically come with the "office". One leader said: "No one would say it directly like this, but leadership, even in Christian circles, is performance and success orientated. Those who can show results are accepted as 'good' leaders." Thus achievement, diligence and efficiency are expected of a leader. That means that a leader has to cooperate, put his/her shoulder to the wheel and do more than just administer what already exists. This reflects the theological presbyterian understanding of servant leadership where elders and leaders carry out their leadership ministry like others as a ministry among many in the body of Christ (Rom. 12:3 ff.). 


\section{Conclusion: servant leadership in Swiss evangelical churches}

Exercising leadership within the context of Swiss culture has its special challenges. An understanding of democratic federalism and a deep-seated distrust of power and people in power seem to impede efficient and strong leadership. So how is it still possible to carry out leadership responsibilities in an effective and positive way? An answer to this can be found in the universal biblical-ethical principle of "servant leadership" 5 as lived by Christ. Jesus embodied "servant leadership" with his whole life (Phil. 2:5-11) and taught this revolutionary message to his disciples (Matt. 20:25-27). The apostles adopted the general leadership principle (1 Peter 5:1-3; 2 Cor. 1,24 ; Acts $20: 28 \mathrm{ff}$.) and made it clear that leaders need to follow Jesus' example by acting as servants, carrying out their leadership as a ministry among other ministries, and dealing with power responsibly (Russenberger, 2005:126 ff.; Guardini, 1995:103).

The following five assumptions summarise the essential elements of servant leadership and their effect on Swiss evangelical churches.

\subsection{Saying yes to Swissness}

"I have become all things to all people" (1 Cor. 9:22). Many pastors and ministers are annoyed or frustrated with the Swiss way of doing things. Saying yes to Swissness means taking it seriously, being responsive to it and accommodating it. Many leaders with strong and dominant personalities probably have to reconcile themselves with Swiss culture first. Workers' demands for democracy and especially their basic distrust of people in power often irritate and hurt many leaders and cause them to become detached from Swiss culture. In order to work effectively, leaders not only have to be able to say yes to Swissness, but also have to begin to appreciate, love and utilise it.

\subsection{Living with "decapitated" hierarchy - in leadership teams}

The Swiss believe in the principle of cooperative leadership and prefer leadership teams to one person rule (Guggenbühl, 1967:48 ff.). Therefore, they constantly seek a "decapitated" hierarchy. Single leadership peaks and outstanding leadership personalities as well

5 Robert Greenleaf, a leadership personality with AT \& T was the first to apply "servant leadership" to the business world (Wright, 2003:279). 
as elitist leadership groups are deselected, overthrown or tied back into broader team work at every opportunity. A leader in Switzerland can only win trust in the long run, if he learns to work in a team of different yet equal partners.

\section{3 "Process management" as an important leadership instrument}

Leading through processing means a leader instigates, stagemanages and controls a process. This approach caters to Swiss culture more than any other leadership instrument. In processing, workers are involved in leadership, decision making and problem solving. They are given the chance to have a say and partial codetermination as it appears to be sketched out in the Bible (Acts 6:17; Jos. 24:15 ff.; Acts 15:1 ff.). This is what really corresponds to the Swiss-democratic disposition and motivates people to work together.

\subsection{Fostering overall unity and the independence of groups}

In order to exercise leadership with lasting effect in Swiss evangelical churches, leaders need to take the tendency to federalism into account. For that purpose leaders first need to cultivate unity. Only solid unity can utilise effective synergy in teams (Seiwert \& Gay, 1996:67), give a strong witness, and build a supportive fellowship (Eph. 4:1 ff.). Secondly, almost contrary to that, another part of the leader's work in the Swiss context is to support a great degree of independence of the different ministry departments and groups. "Natural church development" in Swiss free churches will always strive for autonomous units and reject central leadership.

\subsection{Leadership authority has to be "earned"}

Besides the need for teamwork, a leader must be aware of the fact that, to a great extent, authority and respect have to be earned, because they do not come automatically with the ministry or job. This applies to both spiritual as well as social leadership and management competence.

During this study my conviction has grown that culturally influenced values have to be considered and discussed more in relation to leadership issues in the church. Only then can someone say, using Paul's words: "I have become all things to all people" - a Swiss to the Swiss (1 Cor. 9:22). 


\section{List of references}

AUGUSTINY, K. 2003. Geschichte der Schweiz, in Schweizer Familienforschung auf dem Internet. http://www.genealogienetz.de /reg/CH/histde.html Date of access: 23 Sept. 2003.

BRAUN, D. 2003. Tradition und Effizienz in föderalen Strukturen: das Beispiel des Schweizer Föderalismus. (In Knipping, R., Püttner, F. \& Sturm. G., Hrbek. Europäischer Föderalismus im 21. Jahrhundert. Baden-Baden: Nomos Verlagsgesellschaft. S. 91-108.)

BRÜCK, F. 2002. Interkulturelles Management: Kulturvergleich ÖsterreichDeutschland-Schweiz. Frankfurt am Main: IKO - Verlag für Interkulturelle Kommunikation.

BUND FREIER EVANGELISCHER GEMEINDEN. 2001. Wer leitet die Gemeinde? (Angekündigt.)

DÄNDLIKER, K. 1884. Geschichte der Schweiz. Bd. 1: Mit besonderer Rücksicht auf die Entwicklung des Verfassungs- und Kulturlebens von den ältesten Zeiten bis zur Gegenwart. Zürich: Friedrich Schulthess.

DE VRIES, J. 1961. Keltische Religion. (In Schröder, C.M., Hrsg. Die Religionen der Menschheit. Bd. 18. Stuttgart: Kohlhammer. S. 236.)

EGGENBERGER, O. 1990. Die Kirchen, Sondergruppen und religiösen Vereinigungen: ein Handbuch. 5. Auflage. Zürich: Theologischer Verlag.

FEG

see BUND FREIER EVANGELISCHER GEMEINDEN

FURGER-GUNTI, A. 1986. Die Helvetier: Kulturgeschichte eines Keltenvolkes. 2. Auflage. Zürich: Verlag Neue Zürcher Zeitung.

GUARDINI, R. 1995. Das Ende der Neuzeit - Die Macht. 3. Auflage. Mainz: Matthias-Gründewald-Verlag.

GUGGENBÜHL, A. 1967. Die Schweizer sind anders: die Erhaltung der Eigenart - eine Frage der Nationalen Existenz. Zürich: Schweizer Spiegel Verlag.

HOFSTEDE, G. \& HOFSTEDE, G.J. 2009. Interkulturelle Zusammenarbeit. Kulturen - Organisationen Management. 4. Auflage. München: Deutscher Taschenbuch Verlag.

JANSEN, J. 1931. Gemeinde und Gemeindeführung: Episkopat, Presbyterium oder Demokratie? Kassel: Verlag J.G. Oncken Nachfolger. (Gemeinde und Gegenwart: Studien zur Gemeindefrage im Licht der Schrift und der Geschichte, Heft 2.)

KRAFT, C. 1991. Christianity in culture: a study in dynamic biblical theologizing in cross-cultural perspective. New York: Orbis Books.

LINDER, W. 1999. Schweizerische Demokratie: Institutionen - Prozesse Perspektiven. Bern: Haupt.

LINDER, W. 2002. Politische Kultur. (In Klöti, U., Knoepfel, P., Kriesi, H., Linder, W. \& Papadopoulos, Y. Handbuch der Schweizer Politik. Zürich: Verlag Neue Zürcher Zeitung. S. 26.)

MINICHIELLO, R., Eggenberg, T., Wenk, M., Schicker, M. \& Salvisberg, K. 2002. Glaubensbekenntnis der Bewegung plus: Thun. http://www. bewegungplus.ch/portrait/pdf/glaubensbekenntnis.pdf Date of access: 23 Sept. 2003.

MÜLLER, W. 1975. Zur Geschichte der Alemannen. (In Pöschl, V., Hg. Sallust: Wege der Forschung. Band C. Darmstadt: Wissenschaftliche Buchgesellschaft. S. 20-44.) 
MÜLLER, W.R. 1988. Führungslandschaft Schweiz: was beschäftigt die Schweizer Führungskräfte und was heisst für sie Führung? (In Die Unternehmung. Zürich: Schweizerische Gesellschaft für Betriebswirtschaft. p. 246-262.) (Schweizerische Gesellschaft für Betriebswirtschaft, 42(4).)

NEWBIGIN, L. 1989. Den Griechen eine Torheit: das Evangelium und unsere westliche Kultur. 2. Dr. Neukirchen-Vluyn: Aussaat- und SchriftenmissionsVerlag.

NIEBUHR, R. 2001. Christ and culture. 2nd ed. New York: Harper.

NORTON-TAYLOR, D. 1989. Die Frühzeit der Menschen: die Kelten. 2. Aufl. Reinbek bei Hamburg: Rowohlt Taschenbuch Verlag.

PILGERMISSION ST. CHRISCHONA. 1983. Frucht und Gaben des Heiligen Geistes. Bettingen: Pilgermission St. Chrischona.

PILGERMISSION ST. CHRISCHONA. 1995. Leitbild der Pilgermission. Bettingen: Pilgermission St. Chrischona.

PILGERMISSION ST. CHRISCHONA. 1998. Gemeindeordnung des Vereins Chrischona-Gemeinden Schweiz. Bettingen: Verein Chrischona-Gemeinden Schweiz.

PM

see PILGERMISSION ST. CHRISCHONA

ROEMBKE, L. 2000. Multikulturelle Teams: Risiken und Chancen. Giessen: Campus für Christus.

ROTHLAUF, J. 1999. Interkulturelles Management. München: Oldenburg Wissenschaftsverlag.

RÜEGG, C. 2002. Die privatrechtlich organisierten Religionsgemeinschaften in der Schweiz: ein Bestandesaufnahme und juristische Analyse. Freiburg: Universitätsverlag Schweiz. (Freiburger Veröffentlichungen zum Religionsrecht, Bd. 12.)

RUSSENBERGER, M. 2005. Führungskultur in der Schweiz: eine soziohistorische Studie. Giessen: Brunnen.

SEIWERT, J.L. \& GAY, F. 1996. Das 1 x 1 der Persönlichkeit. 2. Auflage. Offenbach: Gabal .

STADELMANN, H. 1988. Die Verantwortung der Ältesten in unseren Gemeinden: Gemeindedemokratie oder Führungsverantwortung der Ältesten. Waldbronn 2: Verlag Bibel \& Gemeinde. http://bitflow.dyndns.org/ german/HelgeStadelmann/Gemeindedemokratie_Oder_Fuehrungsverant wortung_Der_Aeltesten.html Date of access: 23 Sept. 2003.

TODD, E. 1985. The explanation of ideology: family structures and social systems. New York: Blackwell.

WATTS, R.J. 1996. Schweizerische Identität und der schweizerische Beitrag an Europa: aus der Sicht eines Ausländers. (In Linder, W., Lanfranchi, P. \& Weibel, E.R., Hrsg. Schweizer Eigenart - Eigenartige Schweiz: der Kleinstaat im Kräftefeld der europäischen Integration. Bern: Verlag Paul Haupt. S. 129-142.)

WEBER, M. 1872. Askese und kapitalistischer Geist. (In Weber, M. Gesammelte Aufsätze zur Religionssoziologie. Bd. 1: Die Protestantische Ethik und der Geist des Kapitalismus, 6. Tübingen: Mohr-Siebeck. S. 166 ff.)

WRIGHT, W.C. 2003. Der Beziehungsfaktor: menschenorientiert Führen - Ziele gemeinsam erreichen. Basel: Brunnenverlag. 


\section{Key concepts:}

democracy and leadership

Swiss leadership, historical study of

leadership culture in evangelical churches of Switzerland

Swiss values in leadership

\section{Kernbegrippe:}

demokrasie en leierskap

leierskapskulture in evangeliese kerke van Switserland Switserse leierskap, historiese studie van

Switserse waardes en leierskap 
